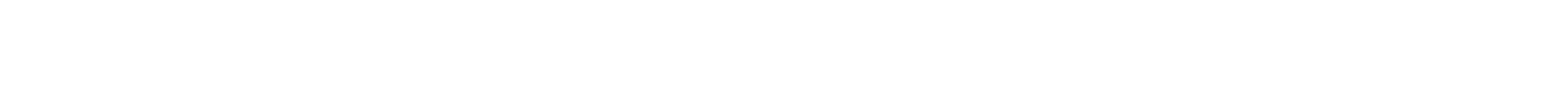 البلسا ولي PVY
}

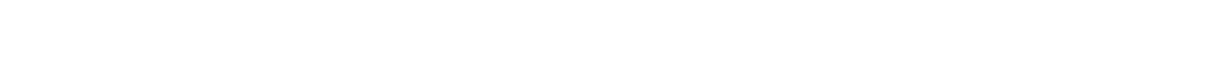 \\ قصم وقاية النبلت \\ كلية الزراعة والغابت \\ جلمعة الموصل \\ (تاريخ الاستلام 23/ 2 / 2010 ؛ تاريخ القبول 10 /5 / 2010)
}

\section{المالهص}

لظٔهرت النتائج أن ش شبانت البطلا بحلمض المللسك تركيز1\% قبل ظهور الأعراض الجهازية عليها بعد تلقيحها بلقاح فايروس البطلا وآي Potato virus Y (PVY) قد أعطى أفضل النتائج في مكافحة الفايروس والحد منشدة الإصابة حيث تلخرظهور الأعراض لغاية 15 -20 يوما من التلقيح بالفايروس، كما

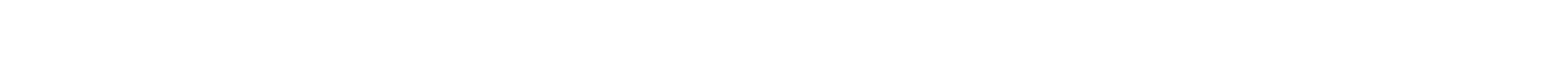
الخضري والوزن الطري للدرنات إذ وصلت أقيلمها إلى 147.05 إنسم و 145.3 غم و 25.8 غم و على التوالي مقارنة بنباتلت معلملة المقارنة المصابة والتي وصلت قيم تلك الصفلت فيها إلى 25.7 اله وسم و

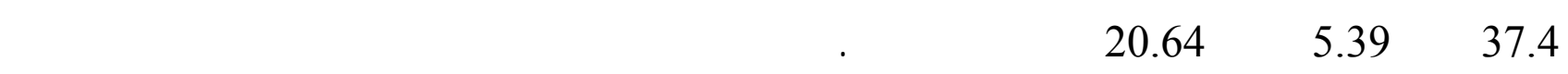

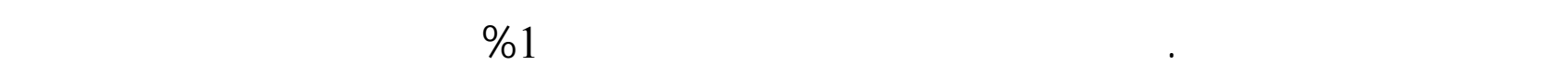

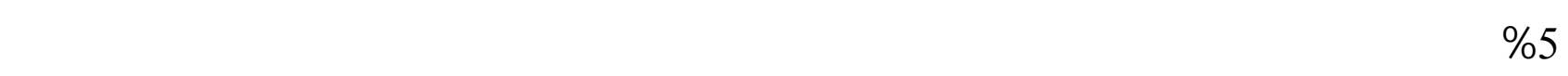

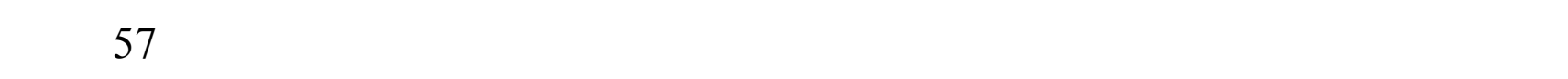

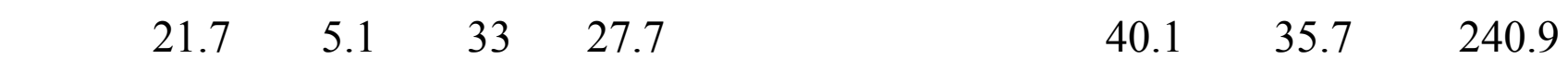
الصفات على التوالي في نباتلت المقارنة المصابة.

الكامل الدالة : فليروس البططا واي ، حلمض السللسلك. 


\title{
The Effect of Salicylic Acid and Liquid Fertilizer on Productivity of Potato Plants Infected by Potato Virus Y (PVY)
}

\author{
Nabeel A. Kassim
}

\author{
Ragad N. Al-Khashab Zainab F. Al-Hashimi \\ Department of Plant Protection \\ College of Agric. \& Forestry \\ Mosul University
}

\begin{abstract}
The results showed that spraying potato plants with salicylic acid $1 \%$ before the occurrence of systemic symptoms after vaccination by Potato Virus $Y$, gives the best results to control the virus and severity of infection, that led to retard symptoms occurrence to 1520 days of vaccination. The spraying also improves plant properties particularly its lengths reached $47.05 \mathrm{~cm}, 145.3 \mathrm{gm}, 25.8 \mathrm{gm}, 48.8 \mathrm{gm}$ respectively, compared with infected plants which were $25.7 \mathrm{~cm}, 37.4 \mathrm{gm}, 5.39 \mathrm{gm} 20.64 \mathrm{gm}$ respectively. While spraying with acid after symptoms occurrence gaves negative results to control the virus. The results showed that spraying by salicylic acid $1 \%$ and fertilization by mineral fertilizer (Multfer $5 \%$ ) gives positive results to control the disease, mitigate its effect on plants and improve its properties. So its lengths reached $57 \mathrm{~cm}, 240.9 \mathrm{gm}, 35.7 \mathrm{gm}, 40.1 \mathrm{gm}$ respectively. Compared with $27.7 \mathrm{~cm}, 33 \mathrm{gm}, 5.1 \mathrm{gm}, 21.7 \mathrm{gm}$ respectively. For the same properties of infected plants .
\end{abstract}

Key words : Potato virus Y (PVY), Salicylic acid. 